\title{
INSTITUTIONALISATION OF RETURN MIGRATION IN LATVIA: THE CASE OF REGIONAL COORDINATORS
}

\author{
Laura Prusakova \\ University of Latvia, Latvia \\ Māris Bērziṇ̌s \\ University of Latvia, Latvia \\ Elīna Apsīte-Beriṇa \\ University of Latvia, Latvia
}

\begin{abstract}
Emigration countries such as Latvia institutionally should address the negative consequences of the ageing populations' economic and demographic challenges. To this aim, in 2018 network of five regional return migration coordinators was established to foster and nationally encourage return migration. The primary function of the regional coordinator is to foster and facilitate requests of potential return migrants.

Drawing on interview materials collected in 2020 with return migration coordinators at the regional level - Latgale, Vidzeme, Zemgale, Kurzeme and Riga, we illustrate good-practice of return migration institutionalisation in Latvia.

Our study focuses on three main fields of interest within the work of regional return coordinators: 1) what are the typical return migration paths from the coordinators' perspective? 2) what are the main challenges in coordinators' work? 3) how education-related issues for return migrants are solved?

The research reveals that people typically return for family reasons and long for their homeland, traditions, and traditional settings. The research states that the main challenges coordinators' work relates to is the low standardisation level as each returnee's case is unique. Keywords: return migration, regional coordinators, qualitative approach, regions, interviews.
\end{abstract}

\section{Introduction}

Studies on return migration is a recognised research topic in most European countries, as emigrants' return helps to address demographic challenges associated with declining and ageing populations (Lang, Glorius, Nadler, \& Kovacs, 2016; Zaiceva \& Zimmermann, 2016). Returnees are often associated with possible economic and societal gains and such aspects as input to labour market and new knowledge are higly valued, however, among returnees the decision-making, reintegration experiences are diverse (Coniglio and Brzozowski, 2018). There are 
Prusakova et al., 2021. Institutionalisation of Return Migration in Latvia: the Case of Regional Coordinators

previous studies concerning socio-institutional aspects upon return (De Haas et al., 2014) and analysis of national policies that stimulate and increase the numbers of potential returnees (Boros and Hegedus, 2016).

Recent research in the European Migration Area has linked the enlargement of the European Union (EU) and labour mobility in the new Member States (Zimmermann, 2005) and the impact of the 2008 economic crisis on return migration (Galgóczi \& Leschke, 2012), considering turbulent economic conditions (Zaiceva and Zimmermann, 2016) and also perception of individual and prolonged crisis and the ways uncertainties are perceived (Apsite-Berina, Manea, \& Berzins, 2020).

Thus, recognising the importance of human capital in recent years, Latvia has paid increased attention to remigration processes and trends at an institutional level. In 2013, the government approved a plan of remigration support measures. However, in 2018, the Ministry of Environmental Protection and Regional Development (MEPRD) and regions planning institutions started to implement a new return migration project - "Supporting your return to your home" or PAPS. It is implemented based on the competence specified in the DPRES Law of the MEPRD and the planning regions and following the tasks set in the Government Action Plan in 2019, which envisages a permanent program. Within the project framework, a network of remigration coordinators was established in Latvia, providing one remigration coordinator in each planning region (Riga, Kurzeme, Vidzeme, Latgale, Zemgale). The coordinators' straightforward tasks include mutual electronic communication with emigrants outside Latvia (PAPS, 2020).

The aim of the paper is to explore the internationalisation of return migration in Latvia. The study raised three main research questions: 1) What are the typical return migration paths from the coordinators' perspective? 2) What are the main challenges in coordinators' work? 3) How education-related issues for return migrants are solved?

\section{Literature Review}

Research on return migration dates back to guest worker recruitment programs, which were widely implemented in several Western European countries in the second half of the 20th century (Cassarino, 2004). As the economy developed, labour was needed in the agricultural, industrial and service sectors, but attracting migrant workers through reciprocal agreements between countries was a quick fix. As labour demand declined, many migrant workers returned to their origin countries (Dustmann \& Weiss, 2007). EU enlargement and labour mobility in the new Member States and the impact of the 2008 economic crisis on remigration explain recent migration studies in Europe (Zimmermann, 2005; Galgóczi \& Leschke, 2012). 
In recent years, improving networking with the Latvian diaspora has become topical in Latvian politics to support and promote Latvian emigrants' return to their homeland (Kḷave \& Šüpule, 2019). One of the main reasons is that returning migrants are seen as potential human capital that can be re-invested in the country of origin. Also, complexity and uncertainty in return migration-decisions have been studied (Apsite-Berina, Burgmanis, \& Krisjane, 2019; Apsite-Berina, Manea, \& Berzins, 2020). Return motives to Latvia mostly relate to the combination of career-related opportunities and nostalgia and family-related moves, which has already been confirmed in several previous studies (ApsiteBerina, Sechi, \& Bērziņš, 2018).

Institutional national or regional level support to potential and actual returnees are essential. Moreover, during the planning of the return it is essenatial to acquire necessary information. Besides policies can be drawn towards particular group of returnees,like, high skilled returnees (Jonkers, 2008), migration programmes for various groups of migrants while tailored policies selectively increase the return (Haddad, 2020). There are countries that are that are thoroughly working return migration strategies, incentive based programmes in Israle distributing general call and focusing on individuals with high added value of the returnee (Cohen, 2009),

\section{Data and Methods}

This study is part of a Latvian national research grant project, "DemoMig" (Development of a Sustainable and Cohesive Latvian Society: Solutions to Demographic and Migration Challenges), which allowed us to gather valuable data in the regions of Latvia. The data was gathered via regional workshops, which employed the "World Café" method and allowed a broad assessment of the regional needs (Apsite-Berina et al., 2021).

In the study, to determine remigration coordinators' opinion on the effectiveness of remigration measures in Latvia, interviews were conducted with the regional remigration coordinators addressed during the DemoMig project. Indepth, semi-structured interviews with remigration coordinators were conducted. Interviews were held with the remigration coordinators of Latgale, Vidzeme, Zemgale and Kurzeme planning regions. A conversation with the remigration coordinators of the Riga planning region took place during the regional brainstorming workshop. The interviews took place according to a previously prepared interview plan. The interview plan was constructed around three blocks, but the interviewees were not limited to commenting on other issues related to the return of Latvian residents:

1. Introduction: acquaintance and personal experience;

2. Work and responsibilities of the remigration coordinator; 
Prusakova et al., 2021. Institutionalisation of Return Migration in Latvia: the Case of Regional Coordinators

3. Questions about the return migration process (education, career, and health care).

The remigration coordinators of the Riga, Latgale and Kurzeme planning regions were interviewed at the DemoMig project's events. Besides, regular communication took place electronically. On-site interviews were documented both by a transcript and electronically with audio recording, with the interviewees' prior consent. All interviewed coordinators were previously introduced to the prepared interview plan. Interviews with remigration coordinators took place in January and February 2020. The average length of one interview was at least one hour.

\section{Results}

This study is based on the interview material with regional return migration coordinators'. Materials allow exploring coordinators' work experience, job responsibilities, benefits and challenges coordinators faced in their daily work. The results achieved so far in the PAPS remigration project are also described.

Since 2013, when the importance of return migration became actual in Latvia, several return migration support programs have been launched. In 2013, the Cabinet of Ministers approved the Re-emigration Support Action Plan 20132016 year (The Cabinet of Ministers, 2013). The aim was to nominate and determine specific support measures for Latvians living abroad who are considering returning to work and/or establish their own business in Latvia, promoting business development. Since 2018, the Ministry of Environmental Protection and Regional Development (MEPRD), together with the planning regions, has developed a return migration support project, "Regional Remigration Coordinator" or "PAPS - Supporting your return to your home". It is implemented in cooperation between the MEPRD and the planning regions, observing the division of competences between the mentioned institutions specified in the Diaspora Law. The program is financed from the state budget. For example, in 2020, its funding was 643,529 euros, of which $30 \%$ is directed to support economic activities, 30\% to ensure the activities of regional coordinators and 30\% to the development of remigration services at the municipal level. The remaining $10 \%$ is spent on administration costs. The program's primary goal is to help returnees returning home and municipalities to re-gain the population (PAPS, 2020).

The regional coordinators' network has been established in each planning region (Riga, Latgale, Vidzeme, Zemgale and Kurzeme) to ensure remigration processes in Latvia. The main tasks of the coordinators are:

- To provide information on services for families with children (including educational opportunities); 
- To provide information on business and employment opportunities;

- To provide information on accommodation options;

- To provide answers to return migrants on other issues in the field of municipal services.

Interviews with remigration coordinators revealed the coordinators' personal experience and previous experience with migration which is diverse. For example, the Latgale region coordinator pointed to her personal migration experience to Great Britain, where she had worked for some time. The Vidzeme region coordinator has no experience of international migration at all. There are also no migrants in her family. The Kurzeme region coordinator does not have personal migration experience, but one family member has lived abroad. The coordinators of the Zemgale and Riga region have had contact with the Latvian diaspora. Latgale and Vidzeme region coordinators have been performing their duties since the project was established. The coordinators of Riga, Kurzeme and Zemgale have started working in this program later. All remigration coordinators have participated in the competition announced by the MEPRD for this vacancy. The primary day-to-day responsibilities of the interviewed coordinators are:

- To maintain proactive communication with clients about opportunities to return to Latvia;

- To help clients with actual issues and problems related to opportunities to return to Latvia;

- To create personalised offers - the coordinator, following the client's interests and needs, prepares and improves the offer. The offers include information on topics of interest to clients - services for families, residence opportunities, business and employment opportunities, job opportunities according to the return migrant's skills and vacancies offered in the region, as well as other vital services that may be of interest to return;

- $\quad$ To improve and update remigration client database information;

- To network with remigration project managers in regional municipalities and other municipal specialists to improve the integration process of return migrants in Latvian municipalities. Cooperation also includes the development of proposals for municipalities to improve services; as well as the adoption of examples of good practice in attracting return migrants to local governments;

- To maintain cooperation with various public administration institutions, including the branch ministry (MEPRD);

- To sustain effective cooperation with other regional remigration coordinators, especially in situations when the client has chosen the municipality of residence in another planning region; 
Prusakova et al., 2021. Institutionalisation of Return Migration in Latvia: the Case of Regional Coordinators

- To organise joint regional events to attract return migrants, including in cooperation with coordinators from other regions;

- To interact with the media and use social networking platforms to communicate with the public, informing about remigration policy initiatives;

- To develop proposals for the improvement of remigration policy;

- To follow changes in regulatory enactments (in the labour market, social support, tax and housing policy).

Remigration coordinators acknowledge that the workload is immense, and they have many responsibilities. Each return migrant's story is different, and it takes much time to create a personalised offer. As illustrated in the quotes below, sometimes the work must be done after working hours:

"No, I cannot manage all my duties during working hours (8 hours a day), I also work on holidays and evenings. Clients are also interested and call in the evenings, as well as communication in social networks" (Vidzeme region remigration coordinator)

"No, it often happens to finish what is started at home. I do a little wrong that I work like this, but only when the work is done, I feel good" (Latgale region remigration coordinator).

Remigration coordinators point out that there is no single system or guidelines for customer service. The Diaspora Law is the primary normative act of remigration policy and administration. The coordinators mentioned that the diversity of return migrants prevents everyone from developing unified management of the process. The coordinators also note that information exchange among authorities should be enhanced:

"The exchange of information is very slow, which is strange, because this is the digital age, but at the moment it seems that only 5\% of information is effectively exchanged" (Latgale region remigration coordinator).

Therefore, remigration coordinators work together and actively communicate with the municipal institutions and even foreign colleagues to make remigration management more successful. For example, seminars are being organised to exchange experiences with Lithuanian remigration coordinators within the framework of projects such as the development of the city of Utena and the reduction of emigration (Globali Utena, 2020). The remigration coordinator needs regular training to understand the needs of return migrants better. All coordinators acknowledged the importance of professional development in this 
position. At the same time, coordinators have both success stories and negative ones, such as:

"Integration into the Latvian education system should be mentioned as the most significant social adaptation problem among return migrant children and young people. These children are often born and have spent most of their lives in their home country and integrated into its environment. Often these children do not speak Latvian or speak very poorly. Another subject and culture is also a big problem in adaptation. Then the school and the return migrant family try to look for these solutions and help" (Kurzeme region remigration coordinator).

"The main problems in the field of education that I have observed in my practice with return migrants are the availability of kindergartens and people's anxiety about whether there are psychologists and assistants in kindergarten. Russian-speaking Latvians are worried that children generally speak only English and communicate with their parents in English or Russian, then they think about how to integrate children without any experience in Latvian into the Latvian education system - kindergartens, schools. Another situation, which is quite common with Latvians returning from Scandinavia, parents quite emotionally perceive differences in education systems, the fact that the child is not assessed with marks elsewhere and then returning to Latvia, it causes stress for both parents and children" (Latgale region remigration coordinator).

Coordinators have observed the main motives for the return and the most common paths of return:

"The motives for returning are different, but mostly it is patriotism, longing for relatives, so many examples where people sit in a car, drive to England and cry, cry for many years, but in the end realise that they want to return home. Many people come back because they look at ideas abroad and then want to go to Latvia to implement them here, and in cases where the return migrant knows about our grants or budgeting opportunities, then this desire to return increases several times" ((Latgale region remigration coordinator).

Some of them are very easily integrated into Latvian society after their return. Common reintegration difficulties relate to finding a job. The coordinator must be able to help in these situations to overcome the difficulties faced by return migrants. Remigrant's most often contact the coordinators to find out the issues they are interested in about health care, social assistance, education, employment and information about housing, and questions about the entry of non-citizens and foreign citizens into Latvia. Often the remigration coordinator is the only person who can help and support in solving everyday issues. Coordinators should also be able to focus on legal and financial issues related to the recognition of various 
Prusakova et al., 2021. Institutionalisation of Return Migration in Latvia: the Case of Regional Coordinators

documents, credit and lending opportunities, entrepreneurship, support funds and tax policy.

The state's involvement in promoting remigration is positive because, since the PAPS project launch in 2018, 4827 families have received support under this program by March 2020, but 463 of them have returned to Latvia (PAPS 2020). Since the Diaspora Law was passed in 2019, support and assistance for return migrants have expanded. The state provides various social support measures, such as free Latvian language training, organises camps for children and youth. The involvement of diaspora organisations and Latvian local governments is also essential in remigration. It helps to implement social support measures for return migrant families. One example of good support is grant competitions organised by MEPRD to support starting own business. Appropriate assistance is provided to all return migrants who seek it.

According to the remigration coordinators, the most frequently mentioned reasons for return are patriotism, longing for the homeland, business start-ups, and of course, family and friends. It has been observed that young families who want to educate their children in Latvia seek help. The main reasons that make it difficult to return to Latvia are fear of finding a suitable job, lower wages, unavailability of housing, ignorance of the Latvian language, unwillingness to cause stress to oneself and family, outstanding credit obligations, as well as distrust of the Latvian education system:

"One of the factors hindering the return of Latvians to their homeland is distrust of the Latvian education system" (Vidzeme regional remigration coordinator)

Fundamental intentions to return are influenced by the fear that the return may fail and risk to have to travel abroad again. Also, for many, the current life abroad is very satisfying, and people do not want to take risks and change their everyday lives:

"Many of them are worried about employment because, over time, they have lost their qualifications, do not have a proper education, or do not know where to look for job vacancies" (Vidzeme regional remigration coordinator)

The coordinators mention that the remigration process is usually not immediate - communication and return planning can take several years. However, each case is very individual. There is also a need for regular measures to improve remigration coordinators' competencies and quality of work. According to the coordinators, remigration would be facilitated by the balanced economic and labour market development of the regions and more even wages throughout the country. Currently, there are more significant opportunities to attract those who have left in the Riga planning region. According to the coordinators, balanced 
regional development would facilitate those who have left even without special remigration programs and support measures.

\section{Conclusions}

In Latvia, increased institutional and academic attention has been paid to the return migration, as the return of previously emigrated groups of the population might positively influence demographic challenges related to the population decline and ageing.

Since 2018, the responsible ministry has implemented a return migration project - "Supporting your return to your home" or PAPS in cooperation with regional planning institutions. The work of regional remigration coordinators is essential in the project.

Similar to previous studies, regional return migration coordinators recognises the importance of patriotism, longing for the homeland, family, and friends as the main factors favouring return (Krisjane et al., 2018; Apsite-Berina et al., 2020). Return to the origin most often is medium or long term project which acquires proactive communication with the regional coordinator, subsequent steps from the intention, decision-making and actual move. Moreover, potential risk assessment is considered, especially if the return of several family members is planned.

The main challenges in coordinators' work are responsibility overload; each return migrant's case is unique; there is a lack of guidelines, a system to ensure more efficient work and communication with institutional bodies. Also, individual resilience capacity for quick adaptation to different situations, changing laws and political situations in the country and globally is essential.

Return migration coordinators acknowledge that the following issues are most often related to education: access to schools and pre-school education, support measures for pupils with foreign educational experience, opportunities to learn the Latvian language, and inclusion Latvian education system.

Return emigration support measures are essential for the success and sustainable return process. In return migration management, it is crucial to improve regulatory enactments, such as the Diaspora Law, and support coordinators' training and mutual collaboration.

\section{Acknowledgements}

The authors are grateful to the regional return migration coordinators. This work was supported by the ERDF grants 1.1.1.2/VIAA/1/16/184 and LZP2020/2-0280 and National Research Program Project grant VPP-IZM-2018/10015 . 
Prusakova et al., 2021. Institutionalisation of Return Migration in Latvia: the Case of Regional Coordinators

\section{References}

Apsite-Berina, E., Bela, B., Berzins, M., Bite, D., Krisjane, Z., Krumins, J., Kruzmetra, Z. \& Lubkina, V. (2021). Regional needs assessment: an approach to demographic and migration research. FOLIA GEOGRAPHICA, 5.

Apsite-Berina, E., Burgmanis, G., \& Krisjane, Z. (2019). Return Migration Trends in Latvia: Re-attracting the Main Human Resource for Sustainable Regional Development. In Proceedings of the 12th International Scientific and Practical Conference. Volume I, Vol. 16, 19.

Apsite-Berina, E., Krisjane, Z., Sechi, G., \& Berzins, M. (2018). Regional patterns of belonging among young Latvian returnees. In Proceedings of the 2018 International Conference' Economic science for rural development, No. 48.

Apsite-Berina, E., Manea, M. E., \& Berzins, M. (2020). The ambiguity of return migration: Prolonged crisis and uncertainty in the life strategies of young Romanian and Latvian returnees. International Migration, 58(1), 61-75.

Cassarino, J. P. (2004). Theorising return migration: The conceptual approach to return migrants revisited. International Journal on Multicultural Societies, 6(2), 253-279.

Cohen, N. (2009). Come home, be professional: ethno-nationalism and economic rationalism in Israel's return migration strategy. Immigrants \& Minorities, 27(1), 1-28.

Coniglio, N. D., \& Brzozowski, J. (2018). Migration and development at home: Bitter or sweet return? Evidence from Poland. European Urban and Regional Studies, 25(1), 85-105.

De Haas, H, Fokkema, T, Fihri, MF (2014) Return migration as failure or success? Journal of International Migration and Integration 16(2), 415-429.

Dustmann, C., \& Weiss, Y. (2007). Return migration: theory and empirical evidence from the UK. British Journal of Industrial Relations, 45(2), 236-256.

Galgóczi, B., \& Leschke, J. (2012). EU labour migration during the crisis-does increased labour mobility contribute to better labour allocation? Social Europe Journal, 7(1), 17-19.

Globali Utena. (2020). What is happening in a global utena society? Find out what kind of events related to global utena project are taking place in utena city or abroad. Globali Utena. Retrieved from https://globali.utena.lt/en/what-is-happening/

Haddad, M. (2020). When states encourage migration. The institutionalisation of French overseas-mainland migration and its effect on migrant selection. Journal of Ethnic and Migration Studies, 1-19.

Hazans, M. (2016). Migration experience of the Baltic countries in the context of Economic Crisis. Kahanec, M., Zimmermann, K. F. (eds.), Labor Migration, EU Enlargement, and the Great Recession. Berlin, Heidelberg, Springer, 1-5.

Jonkers, K. (2008). A comparative study of return migration policies targeting the highly skilled in four major sending countries.

Kḷve, E., \& Šūpule, I. (2019). Return Migration Process in Policy and Practice. Kaša, E., et al. (red.), The Emigrant Communities of Latvia. Nation Identity, Transnational Belonging, and Diaspora Politics. Riga, Springer, 261-283.

Krisjane, Z., Apsite-Berina, E., \& Berzins, M. (2016). Circularity within the EU: the return intentions of Latvian migrants. In R. Nadler, Z. Kovács, B. Glorius, \& T. Lang, (Eds.), Return Migration and Regional Development in Europe: mobility against the stream (pp. 215-240). London: Palgrave Macmillan. 
Krisjane, Z., Apsite-Berina, E., Sechi, G., \& Bērziņš, M. (2018). Juxtaposed intra-EU youth mobility: motivations among returnees to Latvia. Belgeo. Revue belge de géographie, 3 , $1-16$.

Lang, T., Glorius, B., Nadler, R., \& Kovacs, Z. (2016). Introduction: Mobility Against the Stream? New Concepts, Methodological Approaches and Regional Perspectives on Return Migration in Europe. Nadler, R., et al. (eds.), Return Migration and Regional Development in Europe. Mobility Againsts the Stream. London, Springer Nature, 2-15.

Mierina, I. (2015). Ievads. Pētījuma aktualitātes pamatojums. Mieriņa, I. (red.), Latvijas emigrantu kopienas: Cerību diaspora. Rīga, Latvijas Universitātes Filozofijas un sociologijas institūts, 5-11.

PAPS. 2020. Vides aizsardzības un regionālās attīstības ministrijas un plānošanas reǵionu īstenotais projekts "Reǵionālais remigrācijas koordinators". PAPS. Retrieved from: https://www.paps.lv/par-projektu/

The Cabinet of Ministers. (2013). The Cabinet of Ministers instruction no. 356 Par Reemigrācijas atbalsta pasākumu plānu 2013.-2016.gadam. Latvijas Vēstnesis, 150 (4956).

Zaiceva, A., \& Zimmermann, K. F. (2016). Returning home at times of trouble? Return migration of EU enlargement migrants during the crisis. Kahanec, M., Zimmermann, K. F. (eds.), Labor migration, EU enlargement, and the great recession. Berlin, Heidelberg, Springer, 397-418.

Zaiceva, A., \& Zimmermann, K. F. (2016). Returning home at times of trouble? Return migration of EU enlargement migrants during the crisis. In Labor migration, EU enlargement, and the great recession (pp. 397-418). Springer, Berlin, Heidelberg.

Zimmermann, K. F. (2005). European labour mobility: challenges and potentials. De economist, 153(4), 425-450. 